\title{
Speech Level Shift in the Domain of the Elderly Care in Japan by the Indonesian Caregivers
}

\author{
Putu Dewi Merlyna Yuda Pramesti \\ Faculty of Language and Arts, Ganesha University of Education, Bali, Indonesia \\ N.L. Sutjiati Beratha \\ Faculty of Arts, Udayana University, Bali, Indonesia \\ Made Budiarsa \\ Faculty of Arts, Udayana University, Bali, Indonesia \\ I Nengah Sudipa \\ Faculty of Arts, Udayana University, Bali, Indonesia
}

\begin{abstract}
This study aimed at identifying the phenomenon of speech level shift in the domain of the elderly care in Japan and finding out the rationale of the shift. Speech level in Japanese language is defined as the formality and politeness level in an interaction, which in lingustics is related to the use of formal or non-formal forms at the end of an utterance and is usually said as honorific expressions. Speech level shift is a shift from one speech level to another. The subjects of this study were 68 Indonesian caregivers who worked in the nursing homes in Japan. The data were collected in three areas, namely Osaka, Yokohama and Toyohashi. They were collected by recording the speech events between the caregivers and the elderly. The findings of this study indicated that speech level shifts took place in the interaction between the caregivers and the elderly. There were two types of speech level shifts used by the caregivers, namely plus level shift and minus level shift. They took place in the contexts of formal and nonformal speeches between the two speakers and were done by the caregivers to enable the elderly understand their speeches faster.
\end{abstract}

Index Terms-Japanese honorific language, speech level shift, politeness, formal language, non-formal language

\section{INTRODUCTION}

The existence of Indonesian, Vietnamese and Chinese caregivers in Japan in the present time is emerging due to the increasing number of the elderly which then becomes a social issue in the country. The data from the study results by Aging Research Centre indicated that approximatey in 2030 the number of Japanese citizens aged over 60 years old would be 36, 67 million people (31,8\% of the total population). In 2050, the number would be 37, 64 million people (Hirose, Merlyna, 2018, p.2). As a consequence, there is an increasing need of caregivers for the elderly. However, the dispatch of Indonesian caregivers to Japan every year does not fulfill the high demand. The requirement of competence in communicating in Japanese is the most prominent factor which influences it. This fact made the writer interested in choosing this theme. The writer is interested in examining how the Indonesian caregivers communicate in Japanese in the environment and culture different from their places of origin.

Cook $(2011$, p.3658) explains that speech level shift takes place as the speaker as the active agent chooses the politeness strategy of whether he/she wants to use the honorific forms or not and to make sure the message that he/she wants to deliver can be understood well. In the last 15 years, the topic of speech level shift in Japanese has been discussed by many linguists (for examples Barke, 2011; Cook, 1996, 1997, 2008, 2011; Ikuta, 1983; Okamoto, 2009, and others). The data of the prodecessors were collected from telephone conversations, conversations during meetings or interviews, films and other data that contained speech level shift. Those studies revealed that in a conversation, speech level was chosen based on the situation.

In several domains in life, we absolutely have to pay attention to the use of politeness as it is related to interpersonal relationship. Also in the domain of service for the elderly in Japan, politeness plays a very important role, considering the interactions that take place are between young caregivers and elderly people. The results of the preliminary studies that the writer conducted in 2017 revealed a reality different from the honorific concepts of Japanese. The caregivers, who were young people, in interacting with the elderly did speech level shift many times. Many rules of politeness in Japanese honorific concepts were violated. Yet, the speech level shift done by the caregivers when interacting with the elderly did not threaten the elderly's faces. The conversations flowed smoothly among the two interactants. This made the writer interested in examining the phenomenon; about how speech level shift takes place and what types of speech level shift are used by the Indonesian caregivers. Those are the two main problems discussed in this article. 


\section{LITERATURE REVIEW}

\section{A. Japanese Honorific Language}

Kabaya (2009), explains that communication situation in honorific Japanese actually consists of two important variables, which in Japanese language are known as ningen kankei (人間関係) 'interpersonal relationship' and $b a$ (場) 'place'(p.3).

In line with Kabaya (2009), Rahayu (2017, p.10-13) explains that communication doers consist of speakers, writers, listeners and readers. When conducting communication, there are a few aspects that need to be taken into consideration, such as the position of the speaker $(\mathrm{O} 1)$, the interlocutor $(\mathrm{O} 2)$ and the person who they talk about. Also added by Rahayu (2017, p.10); the places where the speeches take place, the goals of the conversations and the topics of the speeches also influence the choice of languge of the communication doers. In Japan, someone's position really determines language choice in speeches; it can be keigo 'polite language' or futsuukei 'common language'. Both speech levels have language choices as markers. Based on the rules of the use of keigo, if the intention is treat the interlocutor to be superior to the speaker, sonkeigo is used. Meanwhile kenjougo is used to lower the condition or the action of $\mathrm{O} 3$ (Suzuki, 1998; Kabaya, 2009).

In Japanese language, speech level is divided into two main groups, namely polite language (keigo) and non-formal language ( futsuukei). Table 1 below will explain levels of speech in Japanese language.

\section{Keigo}

Tsujimura (1992, p. 4-5) explains that keigo can be defined as the words to show respect. Further, it is explained that keigo is the form of special speech used by a speaker due to his/her respect towards the interlocutors and the third person being talked about. In line with this, Hirabayashi and Hama (1992, p. 5) state that keigo is the type of polite language that is used to make the language used by the first person (the speaker or the writer) sound more polite to respect the second person (the interlocoutor or the reader) and the third person (the person who the first and second persons talk about).

TABLE I.

SPEECH LEVEL IN JAPANESE LANGUAGE

\begin{tabular}{|c|l|l|}
\hline \multicolumn{2}{|c|}{ Speech Level } & \multicolumn{1}{c|}{ Explanation } \\
\hline \multirow{3}{*}{ Futsukei } & $\begin{array}{l}\text { The language used in non-formal situation, } \\
\text { among close friends, towards interlocoutors who } \\
\text { are younger or speeches from people of superior } \\
\text { positions to people of inferior positions. }\end{array}$ \\
\hline \multirow{4}{*}{ Keigo } & $\begin{array}{l}\text { The language used to respect the } \\
\text { interlocoutors/the people that are the topics of the } \\
\text { conversations by their actions or conditions. }\end{array}$ \\
\cline { 2 - 3 } & Kenjougo & $\begin{array}{l}\text { The language used to lower the actions or the } \\
\text { conditions of the speakers to respect the } \\
\text { interlocoutors/the people who are the topics of the } \\
\text { conversations. }\end{array}$ \\
\cline { 2 - 3 } & \multirow{2}{*}{ Teineigo } & $\begin{array}{l}\text { The language used in formal situations teineigo } \\
\text { has definite markers, they are the copulas desu } \\
\text { and } \sim \text { masu with all the variations). }\end{array}$ \\
\hline \multicolumn{2}{|c|}{ Source $:$ Rahayu (2017, p.13) }
\end{tabular}

In addition, according to Suzuki (1998, p.23), keigo is determined by social factors. 敬語は、話す相手やその場、 状況、役割、なってきます。年齢、上司、先輩、親しさ、立場の違いによって使い分けていきます。'Keigo wa, hanasu aite ya sonoba, joukyou, yakuwari, nado ni yotte kawattekimasu. Nenrei, joshi, senpai, shitashisa, tachiba no chigai ni yotte tsukaiwaketeikimasu'. Polite language is determined by the position of the interlocoutors, the condition/situation and the atmosphere of the interaction, the age and the superiority/inferiority status of the interactants, and the place of the conversation.

Keigo is determined by the parameters as follow:

1) Age.... old or young, senior or junior

2) Status .... superordinate or subordinate, teacher or student

3) Sex...male or female

4) Familiarity..... insider or outsider

5) Language style.....the language used for daily conversation, the language used in a talk or a lecture

6) Private or public .......meetings, ceremonies, or other activities

7) Education ......whether the interactants are educated or not

The variety of polite Japanese language is divided into 3 types, namely sonkeigo "exalted terms', kenjougo 'humble terms' and teineigo 'neutral terms' (Niyekawa, 1983, p.225). The non-formal variety (futsuukei) is not included in the polite language. The consideration of the use of keigo is the speech context, including the first, the second and the third persons involved. 
Tsujimura (1992, p. 7) also divides keigo into those three further groups. The same explanation is also given by Kaneko (2014, p. 17) 敬語のグルプ、大きく分けると、敬語は三つのグルプがありす。尊敬語と謙譲語と丁寧 語というグルプを使っています。Keigo no gurupu ookiku wakeruto, keigo wa mitsu no gurupu ga arimasu. Sonkeigo to kenjougo to teineigo to iи gurupu o tsukatte imasu。 'Keigo is divided into three groups, namely sonkeigo, kenjougo and teineigo'.

\section{Sonkeigo}

Kaneko (2014), gives limitation that sonkeigo is polite language variety that is used for the interlocutor (p.17). The objective is to show respect directly by treating the interlocutor or the third person to be superior to the speaker. 相手を することに使う。相手を高めて、直接的に敬意を表す。Aite o suru koto ni tsukau. Aite o takamete,chokusetsuteki ni keii o arawasu. 'Sonkeigo is used for the interlocutor, to treat him/her to be superior to the speaker and to show respect towards the interlocutor.

\section{Kenjougo}

Different from the language variety intended to treat the interlocutor to be superior to the speaker, kenjougo is also used to treat the speaker to be inferior to the interlocutor, whose objective is to show respect directly to the interlocutor. Kaneko (2014, p.34) states that 自分がすることに使う。自分を低めて、間接的に敬意を表す。'Jibun ga suru koto ni tsukau. Jibun wo hikumete, kansetsuteki ni keii o arawasu'. 'Kenjougo is used for the speaker himself, to treat him/herself to be inferior to the interlocutor and indirectly show respect to the interlocutor'.

\section{Teineigo}

The variety of polite language used in formal situations is called teineigo. This type is intended to give sense of being polite so that the speaker will be considered polite by the interlocutor or the third peson who they talk about. Kaneko (2006, p.23) describes it as ‘分全体を丁寧な漢字にする’ ‘sentences that entirely show polite language’. According to Kaneko (2006, p. 2014), teineigo is marked by masu and desu. The same explanation is also given by Tsujimura (1992). He states that the use of teineigo form is marked by the use of copula desu at the end of a sentence, the verb form $\sim$ masu, the pattern [ degozaimasu], and the adding of prefixes o/go to nouns, for example [otegami], [go renraku], etc.

\section{B. Politeness}

Studies on language politeness are pragmatic studies as they are related to the factors determining the choice of language in social interactions. The language choice has impact both on the speaker and the hearer (Crystal, 1987, p. 120).Wardhaugh (1987, p.267) states that politeness in language is a language behaviour that takes solidarity, power, familiarity, the relationship status between the participants, and appreciation. Politeness in language is also determined by the awareness of social habits.

According to Ide (1982, p.357), two important factors in Japanese politeness expressions are the grammatical rules which are systemized in the morphological forms of the language that tell about the degree of politeness and the social rules of the people. In addition, there are four main factors that need to be considered in the study of politeness in Japanese, namely social status, power, age, and formality. Ide (1982) proposes three basic rules which are generated from those four factors (p.366). Those three rules are that people should be polite towards people with higher status, they should be polite towards people who have power, and they should also be polite towards older people. The last rule is closely related to this study as the problem investigated is related to the communication between the caregivers and the elderly.

In line with what has been stated by Ide, et al (2016) that the function of politeness in Japan is as a basis of the continuity of communication or in other words whether a conversation will continue or not is dependant on the realization of the politeness in the communication between the speaker, the interlocutor and the person being talked about, Masato (2008, p. 4) also states that politeness in Japanese is as follows. ポライトネスは、対人関係の基本的 な構え一具体的には相手と自分の \{距離の遠近一を伝達する手段となる。Poraitonesu wa taijin kankeino kihontekina kamae- gutaitekini wa aite to jibun no(kyori) no enkin o dentatsu suru shudan to naru : "what is meant by politeness is a basic attitude in humans relationship, which is a way to tell the distance beween the speaker and the interlocutor, whether it is close or distant.'

In Japanese language, politeness in language is marked by the use or the choice of polite language (keigo). Sutedi (2007, p.83) states that in Japanese there is an option of using polite language (keigo) to show respect in interactions with other people. Keigo is defined as the type of language used appropriately according to the interlocutor and the situation as well as the atmosphere of the conversation to show respect to the interlocutor (Masao, 1985, p.131). The same explanation is also given by Nuibe (2006) in his article, that keigo is the expressions said to express 'respecthumiliation', 'familiarity-distance' based on a speaker's relationship with the interlocutor or the consideration of the first person regarding the status, power, respect or disrespect, and the familiarity-distance between the speaker, the interlocutor, and the person they talk about as well as all things related to him/her (p.98-100).

\section{Politeness}

Speech level shift started to take place in Japan when the standard Japanese language started to be implemented in the era of Meiji in the $19^{\text {th }}$ century. Many linguists have discussed about this phenomenon. In the beginning, studies on speech level shift were published in English by Makino (1983, p.2002) and Ikuta in 1983. Both scientists learnt that 
shifts in language styles often took place in Japanese language. Makino in 1983 used speaker-oriented principle to explain the changes that took place, and divided the orientation into two different mechanisms; from the speaker's and the interlocutor's sides. The speaker-oriented mechanism was in the form of motivation to express high subjectivity level and presuppositions (Makino, 1983, p. 143), while the interlocutor-oriented mechanism was when the information was directed directly to the interlocutor. Makino in 2002 then focused on the changes from the use of formal to informal expressions and conducted in-depth analysis on the psychological motivation for a few shifts. Makino said that the shift took place because the speaker wanted to express ideas to the interlocutor. In his analysis which aimed at understanding the different mechanism that influenced a language shift, the social and interpersonal factors were not fully revealed. Ikuta (1983) states a different opinion; that shift is related to distance. Ikuta explains that the formal type adds distance and non-formal type reduces distance.

Yoshida and Sakurai (2005) who base their researches on casual conversations state that Japanese speakers shift to index their role identities. They argue that speakers are very creative in using the polite language when conversing with friends or family members to mark their socio-cultural identities. This study needs to be noted as it shows that in informal situations, factors like status and age difference is irrelevant to language style shift. Their observation is very crucial to understand this phenomenon and stresses the need of differentiating formal and informal interactions. There are two types of shifts, namely plus level shift and minus level shift.

\section{Plus Level Shift and Minus Level Shift}

General level shift means that honorific forms, especially the forms of masu/desu as a part of verb form in the predicate, are not used in certain interactions and change to simple forms (minus level shift). Level shift also includes shift from common form to masu/desu forms (plus level shift). Studies on level shift currently attract more attention, or in other words are new kinds of studies in researches on politeness, and challenge the politeness concept. Minus level shift means that the people that interact basically use polite forms of language, but simple forms occur from time to time to index certain psychological shifts. Ikuta (1983), after examining a TV interview, reported that the participants normally used the desu/masu forms, but the interviewer used simple form to show "empathy" to the people that he/she interviewed. Maynard (2001) studied a TV drama where two people fell in love and the shift indicated the up and down of their emotion. He finally concluded that the $d a$ form (the simple form) indexed "familiarity, tolerance, and fun". Applying the same technique, Takeda (2011) reported that minus level shift took place when the speaker expressed his/her feelings, showed empathy towards others and emotionally involved in other stories. Different from those three linguists, Makino (2002) examined the data from a round table discussion. The aim of his study was to find out the index of the non-formal form towards the low involvement of the speakers and the interlocutor. He called this "direction of inner communication" (Makino, 2002, p. 123).

Takeda (2011) also found out that the non-formal form took place when the speaker gave the impression that he/she talked to him/herself. This is in line with "innate mode" as stated by Cook (1996b) and "inner thought" as stated by Saito (2010). Chin (2003) examined the conversation between two young adults of the same age who just met and reported that common form took place often when the speaker thought about appropriate words to say or tried to remember something when he/she spoke. Saito (2010), after examining data in forms of non-formal language between subordinates with the superiors at the working place, reported that the non-formal forms took place when they highlighted information (for example giving opinion, clarifying superior's commands)

\section{METHODOLOGY}

\section{A. Participants}

The subjects of this study were 68 Indonesian caregivers who worked in three regions in Japan, namely Okayama, Toyohashi and Yokohama. They came from Java, Sumatra, and Bali. All of the informants had JLPT N3 and national nursing lisence. Their mother tongue was Indonesian. Among the 68 caregivers, 5 of them were male. The age requirement of being respondent is between 18 until 30 years old. In one day, they worked for 6 hours, depending on the shift at the nursing homes where they worked. While the elderly chosen as informants were those who were 65 until 105 years old and had been in the nursing home for more than one year.

\section{B. Data Collection}

Data collection was conducted using a few methods. The first method was observation method, which was conducted by applying recording technique; by recording the interaction between the Indonesian caregivers and the elderly. The data resulted were in forms of utterances of the Indonesian caregivers. The second method was interview, which was done by conducting in-depth interviews with the caregivers and the elderly. These in-depth interviews aimed at finding out the things related to the research topic that were not answered by the data in the forms of the utterances. Interviews with the elderly were conducted to find out the responses of the elderly towards the utterances said by the Indonesian caregivers. The third method was distributing questionnaires to 68 informants who were the subjects of the study. The data expected to be collected by distributing the questionnaires were the types of vocabulary choice used by the caregivers in the speech situations and the caregivers's reasons of using those vocabulary. 


\section{Data Analysis}

The data which were collected by recording the conversations of the Indonesian caregivers and the elderly were transcribed, glossed and classified based on the research questions that the writer wanted to answer. The analysis of the utterances was then done by linking the meanings of the utterances with the speech context.

\section{RESUlT \& DiscusSION}

The example of data analysis below would tell about how the phenomenon of speech level shift took place. The discussion will be divided into two parts, namely plus level shift and minus level shift. Each type of level shift will be explained with one or two data analysis. In Japanese language, speech level shift is speech level shift at the end of sentences. Analysing speech level shift will enable us to better understand the functions of several elements related to politeness. As speech level shift is a dynamic phenomenon in conversations, we have seen it from global and local perspectives. In global level, we have seen the frequency of the occurrence of speech level shift in all utterances in conversations and by every speaker. In local level, we have seen the factors that influence the occurrence of the shift and the function it carries in the conversations.

\section{Minus Level Shift}

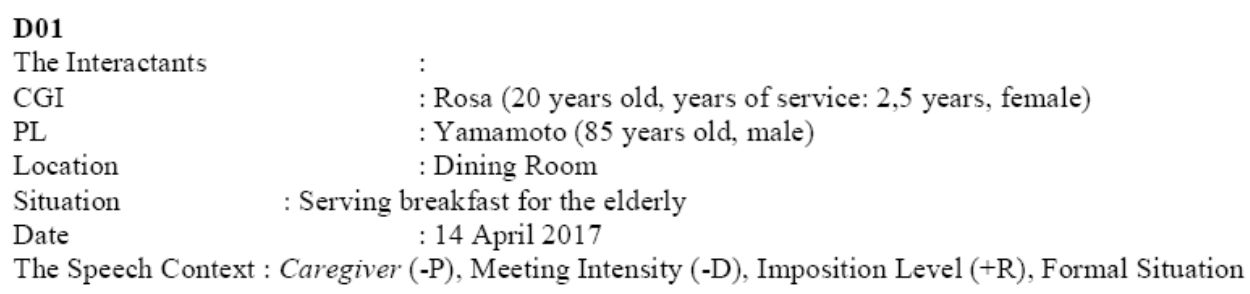

CGI :やまもとさんお茶ぬくいのがいいですかつめたいのがいいですか。(a)

Yamamoto san, ochanukui no ga ii desuka, tsumetai no ga ii desuka.

Mr. Yamamoto, would you like to have warm tea? Or cold tea?

PL :あついのがいい。

Atsui no ga ii.

I'd like to have hot tea.

CGI :あついのがいい。(b)

\section{Atsui no ga ii.}

The hot one?.

PL :ぼけ あつい。 Boke atsui.

Very hot.

Speech Context/Situation: part of conversation (01) was an interaction between an Indonesian caregiver and an elderly at the dining room during breakfast. The caregiver started the conversation by offering tea to the elderly and she asked whether he wanted hot or cold tea. The analysis is that in the domain of elderly service, formal language is mostly used by all interactants, while in certain speech contexts, the non-formal language is also often used by the caregiver when interacting with the elderly. According to Usami (2001), the use of utterance without politeness marker functions as a strategy to avoid admission of hierarchical relationship between the speakers and the interlocutors. When the Indonesian caregiver talked to en elderly patient, utterances without politeness marker were often used to remain neutral. However, when talking in situations involving patient's privacy, the caregivers displayed tendency to use formal language.

It can be observed from utterances (a) and (b) that the Indonesian caregiver in both utterances used speech level at the end of the sentences. In utterance (a) when offering the elderly whether he wanted hot or cold tea, the Indonesian caregiver asked by using formal language (teineigo). After listening to the response of the elderly that chose hot tea, in utterance (b) the Indonesian caregiver confirmed the elderly's choice by saying an utterance without politeness marker or without copula (desu) and question word (gimonshi) $\sim k a$. In Japanese language, the question word (gimonshi $\sim k a)$ can be replaced by using rising intonation like in utterance (b).

Analysis on Plus Level Shift 


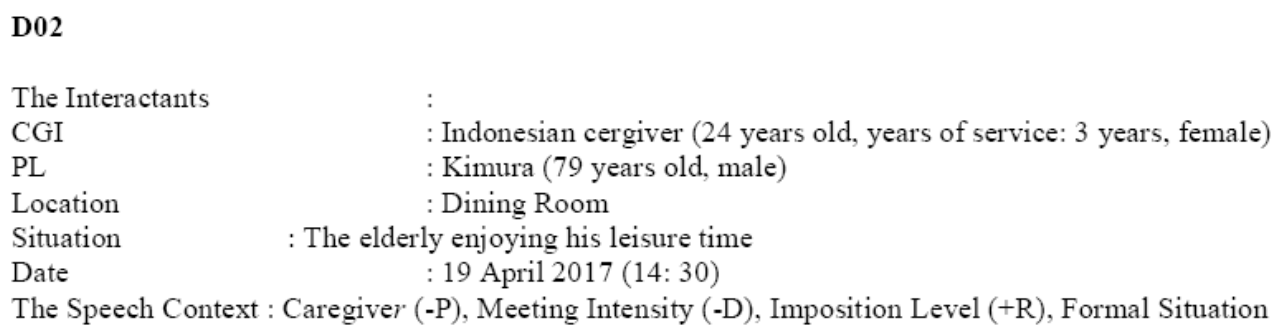

Utterance Context/Situation: conversation (02) above took place in formal situation at the dining table when the elderly was enjoying his leisure time and watching TV after having lunch. The Indonesian caregiver approached an elderly who seemed to be feeling cold.

If we examine utterances (a) and (b) of the Indonesian caregiver, it can be seen that speech level shift took place at the end of the sentences. In utterance (a) the caregiver used non-formal language (futsuukei) when asking 'if the elderly patient was feeling cold or not?', indicated by the use of adjectives without copula $\sim d e s u$ and the question word $\sim k a$. However, when the question did not get any response from the elderly, in utterance (b) the caregiver changed his utterance with formal language and he added an article by saying the patient's name with +san. From the result of the interview, it was known that the caregiver initially wanted to get an immediate response from the elderly so he used non-formal language in utterance (a). Yet after receiving no response, the caregiver called the elderly patient's name and repeated the question in utterance (a), but this time he added the patient's name in the beginning completed with the article $\sim$ san. The purpose of the shift from utterance (a) to utterance (b) by the Indonesian caregiver is acceptable and often done when repeating question or when confirming something important. Both examples of analysis enable us to understand better the reasons behind the choice of the utterance type and the occurrence of the phenomenon of speech level shift in the domain of the elderly care.

The results of the analysis indicated that the main factor determining speech level is the content of the conversation. Both interactants in the domain of the elderly care in the communication process used speech level that already suited the conversational rules in the work of the caregivers. The relationship between both interactants can be understood by seeing three social factors, namely social distance (D), power $(\mathrm{P})$, and the imposition rank (R). Those three factors can be examined to see the role that a speaker can play in his/her linguistics behaviours. The use of appropriate speech level is determined by the hierarchical relationship between the speaker and the interlocutor, the context of the conversation, the context of the situation, etc. The degree of familiarity is regarded the same as sosial distance in politeness strategy, while hierarchy is regarded the same as relative power.

Among the three social factors proposed by Brown and Levinson, social distance and power did not give significant effect on the occurrence of speech level phenomenon. The one that gave big effect was the context of the situation of the speech that influenced the rank of imposition of a speech. In other words, the social distance between both interactants was really low. This indicated that the high frequency of the occurrence of speech level shift phenomenon in the domain of elderly care was caused by the fact that in the domain of the elderly care, distance or power did not significantly give effects on the choice of speech by the caregivers. The one which gave effects was the rank of imposition ( $\mathrm{R}$ ) on each context of the speech situation of every interaction between both interactants.

From the results of the interviews with the caregivers, a few reasons of the caregivers related to the use of the speech level were revealed. The intentions to deliver the message of the speech promptly, to make the elderly feel comfortable by using the language that made them feel like a family member, and to give understanding about the time for doing something were the reasons of the use of minus level shift. While the use of plus level shift took place when the caregivers tried to explain the benefits of an activity of to give explanation to the elderly.

\section{CONCLUSION}

In this study, there were two kinds of speech level use revealed, namely plus level shift and minus level shift. There were some reasons behind the occurrence of both shifts. The reasons of using minus level shift were the intentions to deliver the message of the speech promptly and to make the elderly feel comfortable by using the language that was usually used to talk with a family member so that the elderly would not feel awkward or embarrassed. While the reasons 
of using plus level shift were the caregivers tried to explain the benefits of an activity or to give explanation to the elderly.

\section{ACKNOWLEDGEMENTS}

This article is the second article as the output of the PKPI 2018 program, which is funded by the Ministry of Research, Technology and Higher Education. Therefore, the writer would like to thank The Ministry of Research, Technology and Higher Education for the opportunity given to the writer to participate in the PKPI 2018 program. The writer would like to thank and appreciate those who have contributed to this current study, especially the supervisors: Prof. Dr. N.L. SutjiatiBeratha, M.A.; Prof. Dr. Made Budiarsa, M.A.; Prof. Dr. I NengahSudipa,M.A. for their criticism, comments and suggestions. Thank are also expressed to Prof. Eishi Hirose for the guidance in completing this article during the PKPI or Sandwich Like program 2018 at Shizouka University of Art and Culture Japan.

\section{REFERENCE}

[1] Barke, Andrew. (2011). Situated functions of addressee honorifics in Japanese television drama. In B.L. Davies, M. Haugh, and A.J. Merrison (eds.), Situated Politeness, London: Continuum International Publishing Co., pp. 111-128.

[2] Brown, P., \& Levinson, S. C. (1987). Politeness: Some universals in language usage. Cambridge: Cambridge University Press.

[3] Cook, Minegishi Haruko. (1996a). Japanese language socialization: Indexing the modes of self. Dicourse Processes 22: 171197.

[4] Cook, Minegishi Haruko. (1996b). The use of addressee honorifics in Japanese elementary school classrooms. In N. Akatsuka, S. Iwasaki, and S. Strauss (eds.), Japanese/Korean Linguistics 5. Stanford: CSLI Publications, pp. 67-81.

[5] Cook, Minegishi Haruko. (1997). The role of the Japanese masu form in caregiver-child conversation. Journal of Pragmatics 28: 695-718.

[6] Cook, Minegishi Haruko. (2008). Style shifts in Japanese academic consultations. In K. Jones, and T. Ono(eds.), Style Shifting in Japanese. Amsterdam: John Benjamins Publishing Company, pp. 9-38.

[7] Cook, Minegishi Haruko. (2011). Are honorifics polite? Uses of referent honorifics in a Japanese committee meeting. Journal of Pragmatics 43: 3655-3672.

[8] Crystal, and Davy. (1975). Advanced Conversational English. London : Longman.

[9] Hirose, Eishi, and Merlyna. (2018). Analysis of Politeness from the Results of the Questionnaires given to the Indonesian Caregivers at the Elderly Care Homes. Dissemination of Research Results at A Public Lecture at Udayana University on April $2^{\text {nd }} 2018$ (unpublished).

[10] Ikuta, S. (1983). Speech level shift and conversational strategy. Language Sciences, 5 (1), 37-53.

[11] Kabaya, Hiroshi. et all. (2009). Keigo Hyougen [Keigo Expressions]. Tokyo : Taishukan.

[12] Kaneko, H. (2014). Nihongo Keigo Toreeninggu [Training on Japanese Keigo]. Tokyo : PT Ask.

[13] Makino, Seiichi. (2002) When does communication turn mentally inward?: A case study of Japanese formal to-informal switching. In N.M. Akatsuka, and S. Strauss (eds.), Japanese /Korean Linguistics, Vol. 10. California: CSLI Publications, pp. 121-135.

[14] Masao, Hirai. (1985). Nandemo Wakaru Shinkokugo Handobukku [Handbook on How to Understand Modern Japanese]. Tokyo : Sanseido.

[15] Maynard, K. Senko. (2001). Koisurufutari no kanjookotoba: Doramahyoogen no bunseki to nihongoron [Emotional language between the couple in love: Analysis of expressions in a drama and discussion on Japanese language]. Tokyo: Kurosio Shuppan.

[16] Maynard, K. Senko. (2004). Danwa Gengogaku [Linguistics of Discourse]. Tokyo: Kurosio Shuppan.

[17] Niyekawa, Agnes M. (1983). Honorific Language in Kodansha Encyclopedia of Japan. Tokyo : Kodansha.

[18] Nuibe, Yoshinori. (2006). Nihongo Kyoikugaku Gengo Koudou to Shakai Bunka [Linguistik Pragmatik Pendidikan Bahasa Jepang dan Budaya Sosial]. Japan : 3A Network.

[19] Okamoto, Shigeko. (2009). Politeness and perception of irony: Honorifics in Japanese. Metaphor and Symbol 17: 119-139.

[20] Rahayu, Ely Triasih. (2017). Konstruksi Tuturan Bahasa Jepang. Yogyakarta : Erhaka Utama.

[21] Sachiko, Ide. (1982). Japanese Sociolinguistics Politeness and Women Language. Lingua 57.357-385. North Holand Publishing Company. North Holand.

[22] Suzuki, Yukiko. (1998). Utsukushii Keigo no Manaa [Manner of The Use of Proper Keigo]. Tokyo : Miryoku Bijutsu.

[23] Tsujimura, Toshiki. (1992). Keigo Ronkou [Theories of Keigo]. Japan.

Putu Dewi Merlyna Yuda Pramesti was born in Singaraja, Bali, Indonesia. She obtained her Master Degree in Linguistics in 2008 from Udayana University, Bali, Indonesia. She is currently a doctorate candidate in Linguistics at Udayana University and her main research is focused on Linguistics Pragmatics.

N.L. Sutjiati Beratha is a Professor in Linguistics at Udayana University, Denpasar, Bali, Indonesia. She received her Master of Arts (M.A.) in Linguistics from Monash University Australia in 1989, and her Doctor of Philosophy (Ph.D) in Linguistics from The Australian National University, Australia. She has supervised many theses and doctorate dissertations. She has participated in numerous national and international conferences and has written a lot of books and articles. 
Made Budiarsa is a Professor in Linguistics of Udayana University, Bali, Indonesia. He obtained his Master Degree in Linguistics from Sydney University in 1988, and his Doctorate from Gajah Mada University, Indonesia in 2006. He has published many articles and books. His research interest are pragmatics and sociolinguistics. He has participated in many national and international conferences and workshops.

I Nengah Sudipa is a Professor in Linguistics at Udayana University, Denpasar, Bali, Indonesia. He received his Master of Arts (M.A.) in Linguistics from Monash University Australia in 1988, and his Doctorate in Linguistics from Udayana University, Bali, Indonesia in 2004. He has been a supervisor from numerous theses and doctorate dissertations. He has published many articles and books, and actively participated in national and international conferences. 